Article

\title{
The Effect of Market Orientation on Performance of Sharing Economy Business: Focusing on Marketing Innovation and Sustainable Competitive Advantage
}

\author{
Youn Kue $\mathrm{Na}^{1}$, Sungmin Kang ${ }^{2, *(1)}$ and Hye Yeon Jeong ${ }^{3}$ \\ 1 Department of Art and Culture Research Institute, Chung-Ang University, 84 Heukseok-ro, Dongjak-gu, \\ Seoul 156-756, Korea; nyk901@gmail.com \\ 2 College of Business and Economics, Chung-Ang University, 84 Heukseok-ro, Dongjak-gu, \\ Seoul 156-756, Korea \\ 3 Department of Fashion Business Management, FIT (Fashion Institute of Technology), SUNY (State University \\ of New York) Korea, 119 Songdo Moonhwa-ro, Yeonsu-gu, Incheon 21985, Korea; hyeyeon_jeong@fitnyc.edu \\ * Correspondence: smkang@cau.ac.kr; Tel.: +82-10-2243-8647
}

Received: 21 December 2018; Accepted: 28 January 2019; Published: 30 January 2019

\begin{abstract}
This study investigated relationships among the market orientation of sharing economy business, marketing innovation, sustainable competitive advantage (SCA), and performance. Attempts are made to understand market orientation from cultural and behavioral perspectives to accelerate marketing innovation and identify measures for SCA and performance building. Frequency, reliability, validity, fitness, and path analyses were performed on 400 respondents, and a structural model was used. The results are as follows. First, functional coordination of the cultural market orientation of sharing economy business with consumer orientation significantly affected product innovation, but competitive orientation's effect on product innovation was not significant. Competitive orientation and functional coordination significantly affected communication innovation, but consumer orientation's effect on communication innovation was not significant. Second, market information generation and response to market information of behavioral market orientation of sharing economy business significantly influenced product innovation, but market information exchange's influence on product innovation was not significant. Even though market information exchange and response to market information had a significant influence on communication innovation, the influence of market information generation on communication innovation was not significant. Third, both product and communication innovation of the marketing innovation of sharing economy business significantly influenced SCA. Fourth, the SCA of sharing economy business significantly influenced market dominating power.
\end{abstract}

Keywords: sharing economy business; market orientation; marketing innovation; sustainable competitive advantage; performance

\section{Introduction}

Economic activity is expected to transition to a "cooperative sharing society" in which economic activity will gradually shift from "ownership" to "access based sharing", and "exchange value in terms of exchanging resources" to "shared value in terms of sharing commons" [1]. As such, the perceptual changes in consumption values have expanded to the concept of "sharing" along with sustainability and the importance of cooperation, and the social movements to establish a better consumption culture by sharing surplus products and services eventually created a new type of business "sharing economy" [2]. The sharing economy started to consume surplus resources more efficiently based on collaborative consumption expressed as collaborative consumption or access-based consumption [3]. 
Most of all, consumers presently also evaluate products based on their product experience rather than on the product (service) itself and they give more value to how they consume than what they consume compared to the past [4].

Due to the increased number of consumers participating in collaborative consumption, sharing companies are also creating new business models and competitively challenging existing companies. Accordingly, the need for discovering the best practice business models of the sharing economy and discussion on the direction of relevant market revitalization have been raised [5]. In such a rapidly changing environment, the ability to quickly restructure strategies and flexibly respond to the market is very important for increasing the firm's performance [6]. Market-focused strategic flexibility is also important, in that a firm's survival and success depend on the ability to deliver superior customer values than that of competitors in the market [7]. From this perspective, a firm's performance increases when market orientation is strengthened because it improves the ability of the firm to meet customers' changing needs [8]. For highly market-oriented companies, the creation of higher customer value than that of competitors is considered to be the goal of establishing and implementing strategies [9]. As such, market orientation has a positive influence on the market performance of the firm and is recognized as a theoretically and practically important factor of competitive advantage [10]. Good predictions of changes by responding to market demands well by achieving sustainable competitive advantage for the company through market orientation are being emphasized [11].

In this context, market orientation in terms of market creation can be considered as value innovation in that it creates a new noncompetitive market for a service or product developed, while it can also be considered as a disruptive innovation in that it leads competition from existing markets to new ones [12]. Most of all, as a source of idea creation, consumer information acquired from the market accelerates innovation in the innovation process [13]. Market orientation, which attempts to satisfy consumers' desires that are being expressed and potential desires that cannot be expressed, expects companies to implement meaningful and new marketing programs [14]. From that perspective, Narver et al. [15] classified market orientation into responsive market orientation that coincides with consumers' expressed desires and proactive market orientation that coincides with desires that consumers were unable to express, such as activities of developing more innovative and new products or services.

Improvement in the ability to create consumer value through marketing innovation is expected to increase the competitive advantage of the firm by making differential implementation of marketing mix possible [13]. Since such an ability to create consumer value can be improved through the learning effect that is acquired from its repetitive use to solve the marketing problems of the firm, it can lead to a sustained competitive edge.

In summary, the present study investigated the relationships among the market orientation of sharing economy business, marketing innovation, sustainable competitive advantage (SCA), and performance to understand market orientation from cultural and behavioral perspectives. This is to accelerate marketing innovation using sources acquired from the market, and to identify measures for SCA and building performance. Especially, the findings are significant in that they can be practical data for creating marketing innovations of sharing economy business firms in South Korea.

\section{Theoretical Background}

\subsection{Market Orientation}

Market orientation is a management thought that overcomes theoretical limitations of marketing concepts and presents practical activity guidelines. It is considered as the processes of discovering and understanding desires of not only existing customers, but also potential ones. It is observing and coping with the activities of existing and potential competitors, allowing a focusing on the knowledge and resources of the firm in solving problems and opportunities derived through such processes and activities that develop the organization and management system [16]. In other words, market 
orientation can be considered as the tendency of organizational activities to respond to the market demand better than competitors and predict market changes well to create a sustainable competitive advantage and high profits [17].

On the perspective and type of market orientation, Narver et al. [15] classified customers' desires into desires that customers can and cannot express. They considered activities to satisfy the desire customers can express as "responsive market orientation" and activities of newly and innovatively developing products and services focusing on customers' unexpressed desires as "proactive market orientation". Kohli and Jaworski [18] explained market orientation from the "perspective of market information" in which market orientation is considered as collecting market information on both current and potential customers, diffusing collected information to departments, and inducing a proper reaction. From the behavioral perspective, they stated that the subject of action is not only the marketing department, but also the entire organization, the target of the action is market information, and furthermore, actions on marketing information are generation, diffusion, and response. Jaworski and Kohli [19] considered market orientation as a marketing practice concept and materialized it into the acquisition of market information across the entire organization for the desires of current and future customers, diffusion of market information to departments, and organizational responses.

Hills and Sarin [20] stated that leading customers is the process of identifying potential desires that customers were unable to express, and such activities can lead the action and preference to a new direction. Yang [21] stated that products and services developed through market-creating market orientation are in line with value innovation [22] from the perspective that they create a new market without competition, while it is a disruptive innovation [12] from the perspective that they lead the competition in the existing market to a new market in the future. Yang [21] stated that such a market orientation can be considered as a systematic value system that can be classified into customer orientation, cooperation between organizations, and competitor orientation [18]. Customer orientation has to sufficiently understand target buyers to continuously create effective value for them [23].

Such a market orientation became a key issue in marketing and strategic organization fields recently and extensive research is being conducted. In connection with this, Jang [11] contended that market orientation influences a firm's performance, level of strategic orientation, relationship quality, and customer retention. Schlegelmilch and Ram [24] empirically investigated the relationship between external environmental factors and market orientation. Furthermore, Conduit and Mavondo [25] stated that a firm's management support, internal communication, human resource management, organizational commitment, information assurance, and organizational integration have positive influences, while interorganizational conflict has a negative influence on internal market orientation. Park and Lee [26] reported that the higher the market orientation, the more improvements in the firm's competence variables consisted of satisfaction, innovation, selection and implementation of competitive strategies, and organizational learning, and customer response variables consisted of customer satisfaction, service quality, service loyalty, and information sharing. Likewise, firms with high market orientation are expected to improve the ability to develop products and services and positively influence technical and managerial innovations, and the influence on managerial innovations is considered to be relatively larger than others [27].

\subsection{Marketing Innovation}

Generally, innovation is defined as the orientation of the firm to experiment with ideas or perform creative processes that can lead to the development of new products [28]. Especially, studies related to marketing innovations have had a lot of interest in innovation types and diffusion processes and emphasized the importance of the role of consumers in the marketing efforts of the firm [29].

In this respect, marketing innovation is an innovation to strengthen marketing practice [30]. It is also considered to be an innovation to increase the competitiveness and performance of the firm by providing improvements and radical solutions for marketing mix related to products, price, distribution, and promotion [14]. Furthermore, marketing innovation capability is a concept that 
includes differentiated brand, [31], product development capability and superior product quality [32], marketing communication capability and advertising differentiation [33], and the business ability of salespeople or sales agents [34]. It also means the ability of the firm to effectively allocate, manage, and implement the resources and capabilities of the firm appropriate for the market condition the firm is facing [35].

The reason why marketing innovation is important is that it provides customers with superior value and it can contribute to sales growth by converting demand elasticity to inelasticity [30]. Improvement in customer value creation through marketing innovation is expected to contribute to the competitive advantage of the firm by making superior implementation of marketing possible [13]. Tamayo-Torres et al. [36] reported that such innovative capability comes from resources, and the capability of such a firm is created by the combination of resources rather than by a single resource. Moreover, the innovation capability of the firm can be further strengthened through the mutual synergy of the resources.

Research has been conducted on the classification of innovation types based on the firm's perspective focusing on the target of innovation and the continuity of technology [37], and the classification of types of these innovation targets was comprehensively carried out from the firm's overall perspective, beyond product innovation. Radical and incremental innovations are representative types according to the classification of types based on the continuity criteria of technology, and mostly product innovation was the target [29]. Depending on the degree of influence on the existing consumption process of consumers, the types of new products are classified into discontinuous innovation, dynamic continuous innovation, and sequential innovation [38]. Furthermore, it has been found that the generic characteristics of innovative products that consumers perceive (such as perceived relative advantage, cost advantage, enjoyment, reliability, ease of use, observability, economic feasibility, and possibility of attempt or use) provide consumers with value and led to their acceptance [39].

To create and maintain competitive advantage in an uncertain environment, the necessity of innovation capability based on the understanding of the market and customers is suggested $[40,41]$. That is, firms should attach importance to innovation capability using intangible resources, such as human resources, rather than developing tangible resources based on investment in equipment or environmental changes, which directly leads to the competitiveness of the firm. In this regard, the firm's competitiveness can be improved by increasing communication capability in the relationship between industrial customers even in marketing innovation [42]. Continuous maintenance of relationships with various parties concerned for nonprofit organizations is more important than anything else, so the organization needs its own differentiated communication capabilities for it to continuously maintain good relationships with them. As relationship marketing becomes important for nonprofit organizations, they have to improve customers' satisfaction with their services through differentiated communication capabilities in order for the organization to maintain continuous relationships with consumers [43].

Thus, innovation strategies are suggested as an essential condition for competitive advantage in the entire process from the production to the sale of the product [30]. Marketing innovation refers to an integrated process of applying knowledge, technology, and resources to create value in the market, and the ultimate goal of marketing capabilities is in increasing the value of the firm and meeting the demand [44].

\subsection{Sustainable Competitive Advantage}

The ultimate goal of strategic management is the realization of competitive advantage, which refers to the creation of more value than competitors. It is a unique competitive status the firm has over competitors through decision making on the distribution and combination of resources and capabilities for the activity areas and goal achievement of the firm. 
Such a concept of competitive advantage refers to achieving superior performance using the resources and capabilities of the organization [45]. It means the capability to create a superior competitive position [46] and superior value for customers based on its greater assets and capabilities, and implies the capabilities of low cost, differentiation, and centralization [47]. The determinants of a competitive advantage are variously classified depending on the purpose of the study, such as cost advantage, differentiation advantage [47], efficiency, quality, innovation, customer responsiveness [48], cost, quality, time, and flexibility [49].

Creation and maintenance of a competitive advantage in the recent business environment is quite necessary for short-term revenue generation or securing the growth of family business. To provide superior value to customers, securing a competitive advantage over competitors is becoming more important than anything else. Jaakkola et al. [50] stated that a sustainable competitive advantage is accomplished through learning effects and the firm's resources that are valuable, rare, difficult to replicate, and irreplaceable. Dwyer et al. [51] contended that firms have to continuously create value that competitors cannot imitate by continuously securing irreplaceable resources and capabilities for them to secure sustainable competitive advantage.

From the resource-based view, core competence can form a competitive advantage specific to the firm [52], and the intangible resources, such as control and learning, that constitute such core competence can be usefully used in developing new products and markets [53]. Strategic imitation of core competence of a firm is generally difficult because the imitating firm has to conduct a series of similar irreversible investments and learning [54]. Leonard-Barton [55] stated that core competence can provide the source of a competitive advantage because it can be institutionalized over a long period of time, become a part of the firm's knowledge-creating system, and rely on unique interrelationships of people who are very hard to imitate, dailiness, and technology.

In the field of management strategy, research is being conducted to determine if the firm's resources and operational characteristics are related to a competitive advantage that creates sustainable performance [56]. Banker et al. [57] stated that a firm will achieve sustainable financial performance when the firm's resources and processes continuously create value in the future. According to previous research on the relationship between strategy and performance, firms can secure a competitive advantage and obtain sustainable performance in terms of profit or cash flow by employing cost leadership or differentiation strategy.

\subsection{Performance}

Many previous studies related to market orientation presented management performance as the dependent variable, and it was presented in a large number of various measurement items. In this regard, $\mathrm{O}^{\prime}$ Cass and Ngo [58] measured performance using the perception of overall brand performance, market share, and sales amount when they investigated the relationship between market orientation and brand performance. Kirca et al. [59] classified market orientation performance into the firm's performance, performance for customers, innovation performance, and performance for customers. Jun and Park [60] stated that because market orientation has significant influence on the customer orientation of employees, the better the hotel deals with the creation, diffusion, and response to information, the higher the customer orientation of employees.

Lee et al. [61] reported that market orientation contributes to performance by increasing customer satisfaction by improving service quality and reducing customer switching costs, influencing customers' word-of-mouth communication. Kim et al. [62] identified that each construct of market orientation forms a cause-and-effect relationship, and the creation and diffusion of information influence trust through information sharing between firms and firm-wide responses. As such, market orientation can improve the market performance of the firm based on a sensitive response to market changes [63], and reported to have a positive influence on product development capabilities, product market share, sales, and earnings [64]. The importance of considering both financial and nonfinancial aspects in management performance measurement is emphasized [60]. 
Market orientation is based on the acquisition of market information and response from sources, such as customers and competitors, so the higher the market orientation of the learning organization, the more improvement in customer satisfaction, and customer satisfaction compared to competitors influence the growth and profitability [65]. The performance of a firm that has a sustainable competitive advantage will increase further as time passes because the firm will have more flexibility in the implementation of marketing mix than competitors [8]. The study of Naidoo [30] reported that the marketing capabilities of a firm can be improved by the learning effect, and continuously increase earnings. Thus, the market performance of the firm can be improved based on its sensitive response to market changes [63].

\section{Research Method and Procedure}

\subsection{Research Model and Hypotheses}

Market creation is active market orientation that leads consumers rather than responding to them, and the more the firm's market orientation is strengthened the better the firm's capability to meet consumers' changing desires, resulting in improvements of the firm's performance [30]. Such market orientation can be understood from the cultural and behavioral perspectives. Market orientation from the cultural perspective means competitor orientation, consumer orientation, and functional coordination [66], while market orientation from the behavioral perspective means exchange, creation, and response to market information [18]. The market orientation from the combined cultural and behavioral perspectives can be considered as a strategic orientation that can accomplish information exchange, creation, and response about consumers and competitors through functional coordination.

Customer orientation, which tries to meet customer's future desires, enables innovations significant enough to rapidly change customers' preferences [20]. Vorhies and Morgan [44] stated that organizations with strong market orientation establish capabilities which can develop products and service brands that can satisfy customers' desires. Market oriented organizations make efforts to actively cope with market responses by establishing an open communication system for sharing market information through functional coordination among the members [67]. Firms that try to create a market focus on the desires of a small number of innovative groups rather than identifying the desires of the general public, and the ideas obtained from such innovative groups accelerate innovations [68]. Day and Wensley [35] stated that the acquisition and exchange of information about the strength and weakness of competitors increase the possibility of developing a marketing mix different from that of competitors. Hills and Sarin [20] stated that the reason why market oriented responses have positive influence on marketing innovation is that the more the firm creates market information and exchanges knowledge of it within the firm for it to respond to the changes in customers' desires and competitors' movements, the greater the increase in innovation.

Weerawardena and $\mathrm{O}^{\prime}$ Cass [13] stated that customer orientation, which tries to meet customer's future desires, enables innovations significant enough to rapidly change customers' preferences, and furthermore, improvement in customer value creation through marketing innovation is expected to contribute to the competitive advantage of the firm by making the implementation of superior marketing possible [13]. As such, the reason why market oriented responses have significant influence on marketing innovation is the creation of market information to cope with the changes in customers' desires and competitors' movements, and the ability of market oriented responses to enhance innovation by increasing the exchange of such knowledge within the firm [20]. As the market response is strengthened, the sharing economy business responds to customers' desire to express, and as a response to such desires, the response of business will be differentiated from existing marketing mix. Consumer information acquired from the market can further accelerate innovation since it is the source of ideas for innovative processes [13]. Exchange and acquisition of information about competitors' strengths and weaknesses will increase the possibility of developing a marketing mix differentiated from that of competitors [35]. Accordingly, market orientation appears to accelerate 
innovations through the development of new marketing mixes for meeting consumers' desires and effective response to competitors' action even from the perspective of sharing economy business.

A sustainable competitive advantage strengthens the firm's market power in the firm's product launch, price lead, distribution channel improvement, and promotion deployment, and the strengthened market power will gradually increase through learning effects, increasing performance [13,30]. Gulati et al. [69] contended that resources, such as information, capital, products, and services, have the potential to maintain and improve the firm's competitive advantage, and marketing innovation through them have significant influence on competitive advantage [8]. Vorhies and Morgan [44] argued that firms can have a capability that is even more difficult to replicate for competitors through interactions among marketing mix by improvement in even any one of the capabilities of the firm. Kumar et al. [8] stated that firms with a sustainable competitive advantage will build performance because they will have more flexibility in the implementation of marketing mix than competitors as time passes. If competitive advantage is sustained, the market power of the firm will be strengthened in the firm's product launch, distribution channel improvement, price lead, and promotion deployment, and the strengthened market power will gradually increase through learning effects, increasing performance [70].

Market creation orientation formed based on potential desires increases meaningful marketing innovation for future consumers, and furthermore, secures a sustainable competitive advantage, which is expected to act as an outstanding achievement of sharing economy business. Based on the discussion above, the following research model in Figure 1 and hypotheses were established.

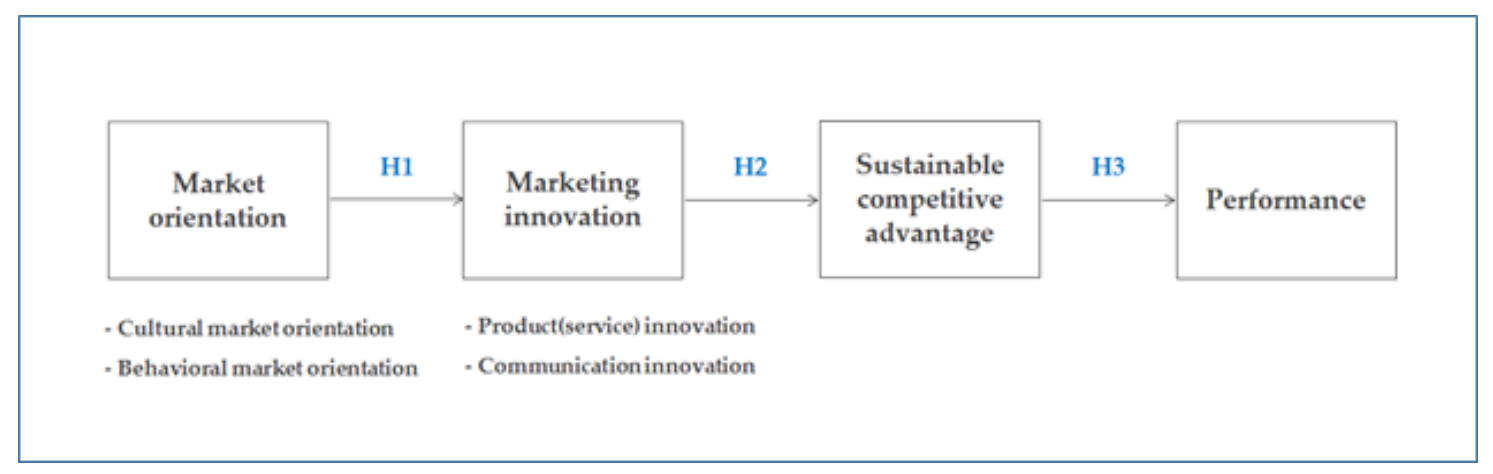

Figure 1. Research model.

Hypothesis 1 (H1). Market orientation of sharing economy business (cultural, behavioral) will positively (+) influence marketing innovation.

Hypothesis 2 (H2). Market innovation of sharing economy business will positively $(+)$ influence sustainable competitive advantage.

Hypothesis 3 (H3). Sustainable competitive advantage of sharing economy business will positively (+) influence performance (market power).

\subsection{Measurement Tools}

The measurement tool for the present study was composed of items of market orientation, marketing innovation, sustainable competitive advantage, and market power of sharing economy business, and demographic characteristics. Market orientation is the point of strategic orientation accomplished through adjustments among the functions of exchange, generation, and response to information about competitors and consumers, and it is composed of cultural and behavioral perspectives based on the studies of Conduit and Mavondo [25], Hills and Sarin [20], Jeong [17], Kohli and Jaworski [18], Kumar et al. [8], Narver et al. [15], Schlegelmilch and Ram [24], Shergill and Nargundkar [14], and Yang and Chung [16]. For market orientation, 19 items were measured. 
For marketing innovation, 7 items were measured by composing innovation in products, costs, transactions, and communication activities as innovation for strengthening marketing implementation based on the studies of Kim and Lee [28], Kumar et al. [8], Naidoo [30], Shergill and Nargundkar [14], Tamayo-Torres et al. [36], Tellis et al. [29], Weerawardena and O'Cass [13], and Vorhies and Morgan [44]. For sustainable competitive advantage, 3 items were measured by composing items so that the competitive advantage factors of sharing economy business consistently produce a superior performance than competitors based on the studies of Dwyer et al. [51], Kumar et al. [8], Reid and Sanders [49], Sigalas [45], Wei et al. [52], Weerawardena and O'Cass [13], and Won and Ryu [56]. Performance was measured using 3 items by composing performance produced as a result of improvements in growth, image, and consumer relationships in the sustainable market of sharing economy business based on the studies of Hult and Ketchen [63], Kumar et al. [8], Jun and Park [60], Naidoo [30], O'Cass and Ngo [58], and Weerawardena and O'Cass [13].

\subsection{Data Collection and Analysis}

The present study collected data through a survey using a 5-point Likert scale questionnaire. To determine the appropriateness of the measuring instrument, the survey was conducted in the following method.

As an initial survey, a marketing scale for market orientation and marketing innovation for sharing economy business was actualized on South Korean experts in sharing economy business using the Delphi technique. As a second analysis, specific contents on a sustainable competitive advantage and influencing factors of performance were extracted by conducting the Critical Incident Technique through open-ended questions on value relationships that consumers actually experienced in sharing economy services using experienced users of sharing economy businesses as the analysis unit. Next, an accurate evaluation was conducted on the survey instrument. The survey was conducted to collect reliable and valid data using convenience sampling. Data collection was conducted through a preliminary and main survey on consumers who have experienced the products and services (campaign) of sharing economy business at each stage.

In the preliminary survey, in March 2017, appropriate items were selected through repeated evaluations and discussions among business administration major graduate students. It was followed by a preliminary survey on 100 people with experience in sharing economy business during April $1-10,2018$. For the purpose of research generalization, the present study selected participants from consumers who have experienced a relevant service of sharing economy business related to space sharing, traffic sharing, object sharing, experience sharing, etc. at least once in the last 6 months using a convenience sampling method, and the main survey was conducted during May 1-30, 2018. Data collection was performed through an online survey company. Questionnaires were distributed through an online and mobile sharing economy community bulletin boards and personal email with prior consent, and the responses were received by e-mail. Survey data were obtained from the total of 420 respondents and relevant data of 400 respondents, which are without missing values, were used for data analysis.

By way of data analysis, SPSS Ver.23.0 statistical package was used for the frequency analysis of the general characteristics of the sample and reliability and validity testing on internal consistency in the present study. In addition, AMOS Ver.23.0 statistical package was used to perform measurement model analysis and path analysis. The relevant analyses are conducted based on the following procedures. (1) Before evaluating the measurement model, Cronbach's $\alpha$ coefficient, which verifies the internal consistency of each research construct, is calculated and presented. (2) In the present study, path analysis is conducted according to the following two stages. In the first stage, exploratory factor analysis and confirmatory factor analysis are used to evaluate the measurement model. Further, a correlation analysis is performed on all the research constructs in order to verify the discriminant validity. In the second stage, path analysis is performed based on the evaluation results of the measurement model. (3) Based on the above path analysis results, the research problem is 
verified by taking into consideration the differences in the analysis results of each model for each measurement factor.

\section{Research Findings and Discussions}

\subsection{Demographic Characteristics of Research Subjects}

The demographic characteristics of the participants were as follows: Gender was equally distributed with $52.0 \%$ (208 participants) male and 48.0\% (192 participants) female; participants in their 20 s were $35.8 \%$ (143 participants), 30s were $34.5 \%$ (138 participants), 40 s were $19.7 \%$ (79 participants), 50 s were $9.3 \%$ (37 participants), and 60 s or older were $0.7 \%$ (3 participants). In terms of marital status, $50.0 \%$ (200 participants) were unmarried and 50.0\% married. For the highest level of education, the highest number of participants were in college/college graduate with $80.3 \%$ (321 participants), followed by $8.3 \%$ (321 participants) in graduate school or higher, 5.5\% (22 participants) in high school graduate or less, and 5.3\% (21 participants) in community college or graduate. In terms of occupation, the highest number of participants were office workers at $33.0 \%$ (132), followed by students at $13.3 \%$ (53 participants), professionals at $12.3 \%$ (49 participants), housewives at $9.3 \%$ ( 37 participants), managers at $8.5 \%$ (34 participants), technicians at 5.8\% (23 participants), public officials at 5.8\% (23 participants), others at 5.8\% (23 participants), unemployed at 3.5\% (14 participants), and sales and service workers at 3.0\% (12 participants). In terms of average monthly household income in Korean Won (KRW) [in U.S. dollar], 40.0\% (160 participants) earned 3 million - less than 5 million KRW [ $\$ 2,788.10$ - less than $\$ 4,646.84], 24.8 \%$ (99 participants) earned 5 million - less than 7 million KRW [\$4,646.84 - less than \$6,505.58], 15\% (60 participants) earned 1 million - less than 3 million KRW [ $\$ 929.37$ - less than $\$ 2,788.10$ ], 10.8\% (43 participants) earned 7 million - less than 9 million KRW [ $\$ 6,505.58$ - less than $\$ 8,364.31$ ], 8\% (32 participants) earned 9 million KRW or higher [\$8,364.31 or higher], and $10.5 \%$ (six participants) earned under 1 million KRW [under \$929.37]. The types of main sharing economy businesses were items sharing (such as clothes, tools, and books) 38.8\% (155 participants), transportation sharing (such as automobile and carpool) 26.5\% (106 participants), space sharing (such as lodge, office, and meeting room) 25.5\% (102 participants), experience sharing (such as knowledge and skills) 8.0\% (32 participants), and money sharing (such as cloud funding and loan) $1.3 \%$ (five participants).

\subsection{Reliability and Validity Test}

Before the evaluation of measurement models, Cronbach's $\alpha$ coefficient, which is a method of testing the internal consistency, was calculated for each research construct to review the reliability. First, factor analysis using Varimax rotation of 19 items that explains factors related market orientation extracted six factors with eigenvalues 1.0 or higher, which were 'consumer orientation (three items)," "competitor orientation (three items)," "functional coordination (three items)," "creation of market information (four items)," "exchanging market information (three items)," and "response to market information (three items)" as shown in Table 1 . The total variance explained by these six factors was $72.442 \%$, and showed a high reliability with all Cronbach's $\alpha$ coefficients equal to or greater than 0.733 . In addition, factor analysis using Varimax rotation of seven items that explains marketing innovation factors extracted two factors of "product innovation (four items)" and "communication innovation (three items)" with eigenvalues 1.0 or higher as shown in Table 2. The total variance explained by these two factors was $67.091 \%$, and showed a high item reliability with all Cronbach's $\alpha$ coefficients equal to or greater than 0.772 . On the other hand, Table 3 shows the results of unidimensionality tests of each variable of sustainable competitive advantage and performance of sharing economy business, and the factor loading of each factor was 0.825 or greater. The reliability of each factor was found to be high with 0.787 or higher. 
Table 1. Reliability and validity analysis of market orientation factors.

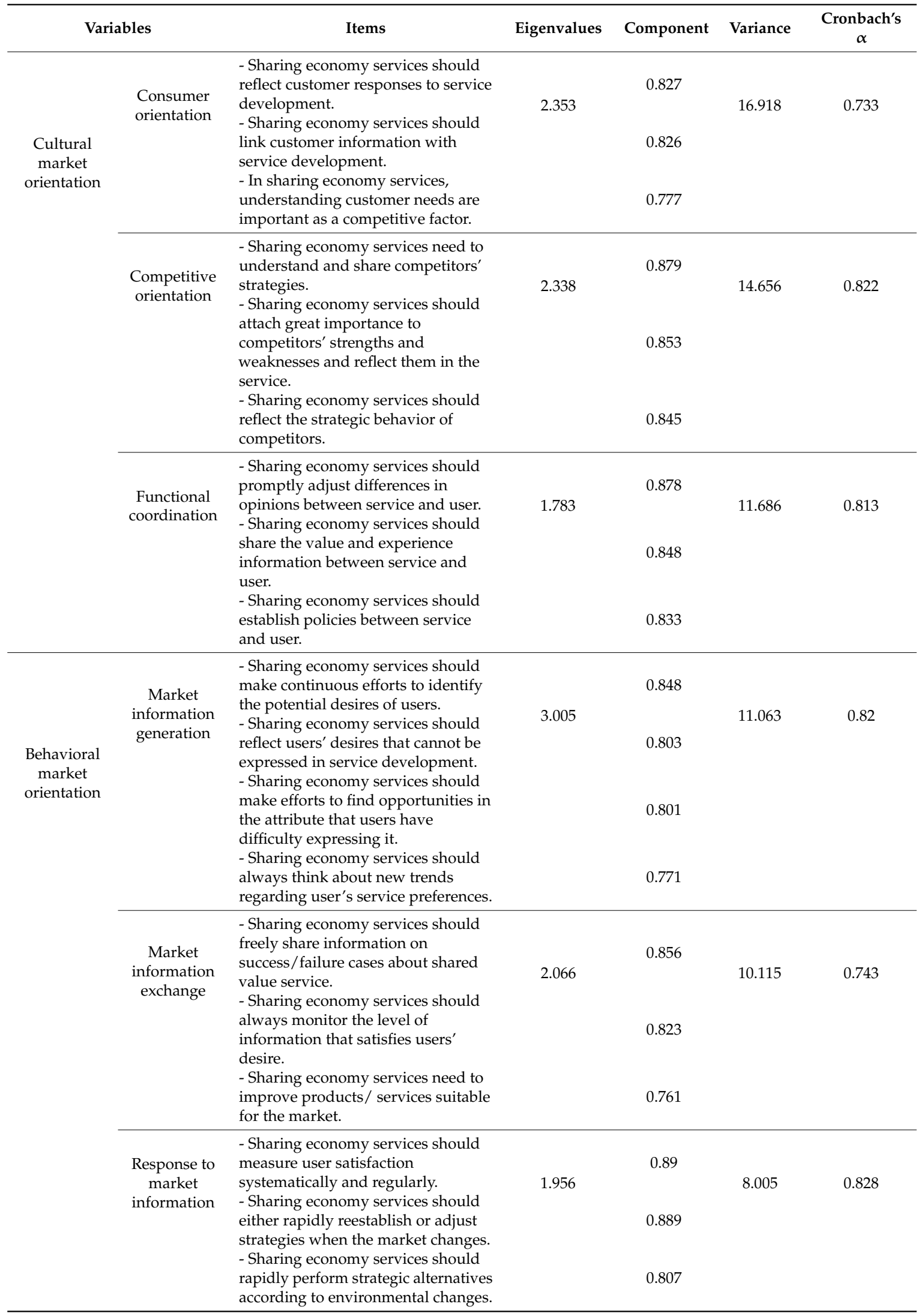


Table 2. Reliability and validity analysis of marketing innovation factors.

\begin{tabular}{|c|c|c|c|c|c|c|}
\hline \multicolumn{2}{|c|}{ Variables } & Items & Eigenvalues & Component & variance & $\begin{array}{c}\text { Cronbach's } \\
\alpha\end{array}$ \\
\hline \multirow[t]{2}{*}{$\begin{array}{l}\text { Marketing } \\
\text { innovation }\end{array}$} & $\begin{array}{c}\text { Product } \\
\text { (service) } \\
\text { innovation }\end{array}$ & $\begin{array}{l}\text { - Sharing economy services } \\
\text { should actively present } \\
\text { innovative new product ideas. } \\
\text { - Sharing economy services } \\
\text { should respond quickly to } \\
\text { market demands. } \\
\text { - Sharing economy services } \\
\text { should actively develop new } \\
\text { products (services). } \\
\text { - Sharing economy services } \\
\text { should actively embrace } \\
\text { user-centered pricing policies. }\end{array}$ & 2.486 & $\begin{array}{l}0.808 \\
0.772 \\
0.753 \\
0.614 \\
\end{array}$ & 35.509 & 0.82 \\
\hline & $\begin{array}{l}\text { Communication } \\
\text { innovation }\end{array}$ & $\begin{array}{l}\text { - Sharing economy services } \\
\text { should have an active promotion } \\
\text { that can express the value. } \\
\text { - Sharing economy services } \\
\text { should integrate various } \\
\text { distribution channels for users to } \\
\text { easily access them. } \\
\text { - Sharing economy services } \\
\text { should have horizontal } \\
\text { communication with consumers. }\end{array}$ & 2.211 & $\begin{array}{l}0.834 \\
0.817\end{array}$ & 31.582 & 0.772 \\
\hline
\end{tabular}

Table 3. Reliability and validity analysis of single factor.

\begin{tabular}{|c|c|c|c|c|c|}
\hline Variables & Items & Eigenvalues & Component & Variance & $\begin{array}{c}\text { Cronbach's } \\
\alpha\end{array}$ \\
\hline $\begin{array}{l}\text { Sustainable } \\
\text { competitive } \\
\text { advantage }\end{array}$ & $\begin{array}{l}\text { - Sharing economy services should } \\
\text { continuously have resources that } \\
\text { can give them a competitive } \\
\text { advantage in the market. } \\
\text { - Sharing economy services should } \\
\text { develop the factors of competitive } \\
\text { advantage so that competitors } \\
\text { cannot easily imitate. } \\
\text { - The competitive advantage of } \\
\text { sharing economy services should be } \\
\text { sustained in the market. }\end{array}$ & 2.156 & $\begin{array}{l}0.864 \\
0.851\end{array}$ & 35.941 & 0.81 \\
\hline Performance & $\begin{array}{l}\text { - Sharing economy services should } \\
\text { have higher market share than } \\
\text { competitors. } \\
\text { - Sharing economy services should } \\
\text { provide better value than } \\
\text { competitors. } \\
\text { - Sharing economy services should } \\
\text { have better brand image than } \\
\text { competitors. }\end{array}$ & 2.154 & $\begin{array}{c}0.85 \\
0.837\end{array}$ & 35.904 & 0.787 \\
\hline
\end{tabular}

\subsection{Confirmatory Factor Analysis}

The results of confirmatory factor analysis are shown in Table 4 below. The measurements of unstandardized coefficient, standardized coefficient, standard error (SE), error variance, critical ratio (CR), construct reliability, and average variance extracted (AVE) value showed that construct validity was secured with all standardized coefficients equal to or greater than 0.6 . Convergent validity was considered to be secured since all AVE values were 0.5 or greater. Internal consistency and convergent validity were also considered to be secured since all construct reliability values were 0.7 or greater. The present study estimated the goodness of fit and parameters of the path analysis through the maximum likelihood method, and the goodness of fit indices of the path analysis for the behavioral 
intention of sharing economy business were $\mathrm{X}^{2}=534.770(\mathrm{df}=8, \mathrm{p}=0.002), \mathrm{GFI}=0.934, \mathrm{AGFI}=0.943$, $\mathrm{RMR}=0.074, \mathrm{NFI}=0.949, \mathrm{CFI}=0.926$, and RMSEA $=0.037$.

Table 4. Confirmatory factor analysis results.

\begin{tabular}{|c|c|c|c|c|c|c|}
\hline $\begin{array}{l}\text { Measurement } \\
\text { Item }\end{array}$ & $\begin{array}{l}\text { Unstandardized } \\
\text { Coefficient }\end{array}$ & $\begin{array}{l}\text { Standardized } \\
\text { Coefficient }\end{array}$ & SE & CR & $\begin{array}{l}\text { Construct } \\
\text { Reliability }\end{array}$ & AVE \\
\hline \multicolumn{7}{|c|}{ Cultural Market Orientation } \\
\hline \multicolumn{7}{|c|}{ Consumer orientation } \\
\hline 1 & 1.000 & 0.688 & - & - & \multirow{3}{*}{0.775} & \multirow{3}{*}{0.680} \\
\hline 2 & 0.998 & 0.833 & 0.057 & 19.066 & & \\
\hline 3 & 0.841 & 0.776 & 0.045 & 15.286 & & \\
\hline \multicolumn{7}{|c|}{ Competitive orientation } \\
\hline 1 & 1.000 & 0.787 & - & - & \multirow{3}{*}{0.907} & \multirow{3}{*}{0.714} \\
\hline 2 & 0.908 & 0.810 & 0.043 & 14.590 & & \\
\hline 3 & 0.884 & 0.750 & 0.037 & 11.575 & & \\
\hline \multicolumn{7}{|c|}{ Functional coordination } \\
\hline 1 & 1.000 & 0.778 & - & - & \multirow{3}{*}{0.857} & \multirow{3}{*}{0.707} \\
\hline 2 & 0.894 & 0.772 & 0.046 & 15.484 & & \\
\hline 3 & 0.851 & 0.776 & 0.035 & 11.742 & & \\
\hline \multicolumn{7}{|c|}{ Behavioral Market Orientation } \\
\hline \multicolumn{7}{|c|}{ Market information generation } \\
\hline 1 & 1.000 & 0.782 & - & - & \multirow{4}{*}{0.884} & \multirow{4}{*}{0.769} \\
\hline 2 & 0.890 & 0.728 & 0.062 & 15.706 & & \\
\hline 3 & 0.879 & 0.713 & 0.043 & 10.957 & & \\
\hline 4 & 0.819 & 0.763 & 0.033 & 8.329 & & \\
\hline \multicolumn{7}{|c|}{ Market information exchange } \\
\hline 1 & 1.000 & 0.796 & - & - & \multirow{3}{*}{0.779} & \multirow{3}{*}{0.666} \\
\hline 2 & 0.860 & 0.763 & 0.064 & 20.123 & & \\
\hline 3 & 0.710 & 0.752 & 0.040 & 13.594 & & \\
\hline \multicolumn{7}{|c|}{ Response to market information } \\
\hline 1 & 1.000 & 0.713 & - & - & \multirow{3}{*}{0.916} & \multirow{3}{*}{0.695} \\
\hline 2 & 0.992 & 0.781 & 0.049 & 16.441 & & \\
\hline 3 & 0.767 & 0.807 & 0.027 & 9.133 & & \\
\hline \multicolumn{7}{|c|}{ Marketing Innovation } \\
\hline \multicolumn{7}{|c|}{ Product innovation } \\
\hline 1 & 1.000 & 0.772 & - & - & & \\
\hline 2 & 0.951 & 0.823 & 0.056 & 14.175 & & \\
\hline 3 & 0.792 & 0.778 & 0.052 & 13.191 & 0.878 & 0.781 \\
\hline 4 & 0.745 & 0.775 & 0.030 & 7.567 & & \\
\hline Communication & vation & & & & & \\
\hline 1 & 1.000 & 0.805 & - & - & & \\
\hline 2 & 0.959 & 0.789 & 0.054 & 18.302 & 0.796 & 0.685 \\
\hline 3 & 0.785 & 0.794 & 0.038 & 12.896 & & \\
\hline Sustainable Com & itive Advantage & & & & & \\
\hline 1 & 1.000 & 0.794 & - & - & & \\
\hline 2 & 0.956 & 0.856 & 0.044 & 14.739 & 0.854 & 0.713 \\
\hline 3 & 0.917 & 0.797 & 0.038 & 12.783 & & \\
\hline Performance & & & & & & \\
\hline 1 & 1.000 & 0.866 & - & - & & \\
\hline 2 & 0.969 & 0.809 & 0.066 & 16.569 & & \\
\hline 3 & 0.864 & 0.826 & 0.045 & 11.255 & 0.811 & 0.779 \\
\hline 4 & 0.724 & 0.749 & 0.041 & 10.419 & & \\
\hline
\end{tabular}

$\mathrm{SE}=$ Standard error; $\mathrm{CR}=$ Critical ratio. 


\subsection{Research Hypothesis Testing}

The test results of research hypothesis of the structural model for the relationship between market orientation and performance of sharing economy business are presented in Figure 2 and Table 5. The test results of each research hypothesis were as follows.

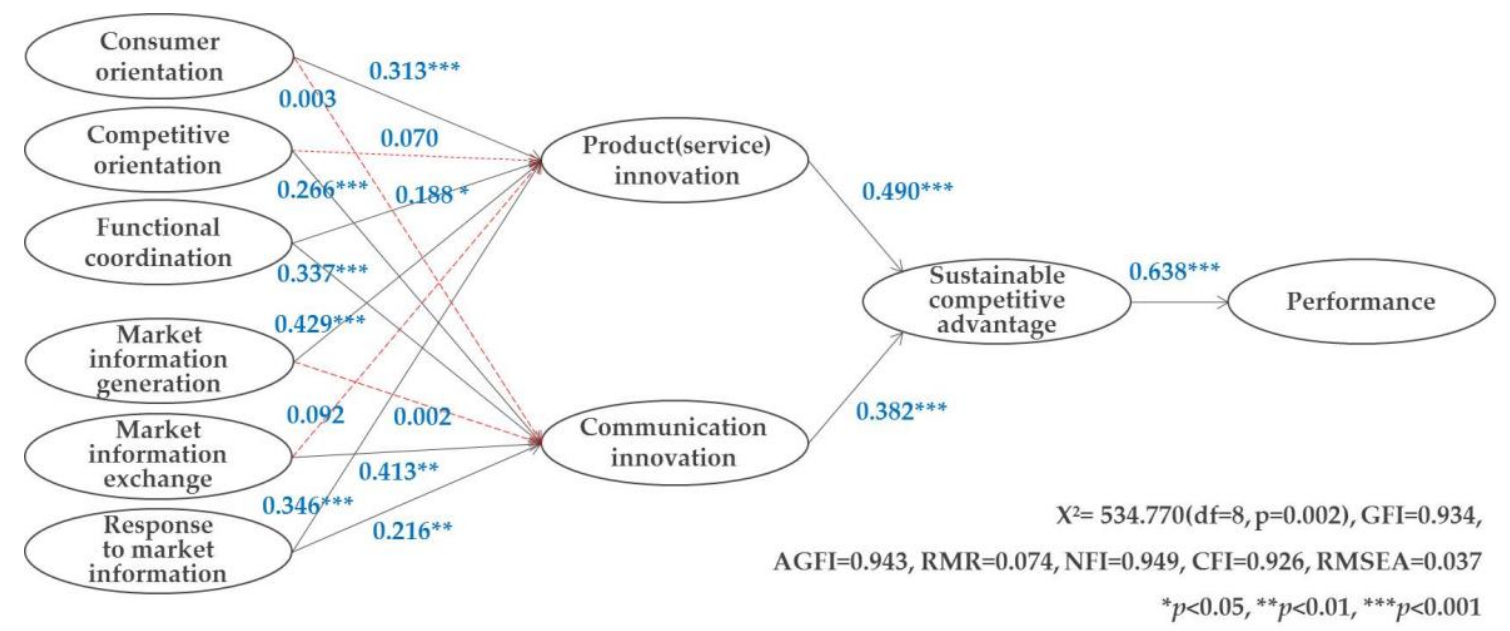

Figure 2. Research results model.

The findings of the present study were as follows. First, the analysis results of the path relationship between cultural market orientation of sharing economy business and marketing innovation showed that product innovation was significantly influenced by consumer orientation $(\beta=0.313, \mathrm{CR}=4.453, \mathrm{p}$ $=0.000)$ and functional coordination $(\beta=0.188, C R=2.582, p=0.010)$, respectively, while the influence of competitive orientation on product innovation was not significant $(\beta=0.070, C R=1.036, p=0.301)$. Even though competitive orientation $(\beta=0.266, C R=4.035, p=0.000)$ and functional coordination ( $\beta=0.337, C R=4.769, p=0.000)$ had a significant influence on communication innovation, the influence of consumer orientation on communication innovation $(\beta=0.003, C R=0.041, p=0.967)$ was not significant. Second, the analysis results of the path relationship between the behavioral market orientation of sharing economy business and marketing innovation showed that product innovation was significantly influenced by market information generation $(\beta=0.429, \mathrm{CR}=5.883, \mathrm{p}$ $=0.000)$ and response to market information $(\beta=0.346, C R=4.893, \mathrm{p}=0.000)$, respectively, while the influence of market information exchange on product innovation was not significant $(\beta=0.092$, $C R=1.296, p=0.196)$. In addition, market information exchange $(\beta=0.413, C R=5.457, p=0.000)$ and response to market information $(\beta=0.216, C R=2.862, p=0.005)$ had a significant influence on communication innovation, but the influence of market information generation $(\beta=0.002, \mathrm{CR}=$ $0.022, \mathrm{p}=0.982$ ) on communication innovation was not significant. Third, the analysis results of the path relationship between the marketing innovation of sharing economy services and a sustainable competitive advantage showed that a sustainable competitive advantage was significantly influenced by product innovation $(\beta=0.490, C R=10.579, \mathrm{p}=0.000)$ and communication innovation $(\beta=$ $0.382, \mathrm{CR}=8.240, \mathrm{p}=0.000$ ). Fourth, the analysis results of the path relationship between the sustainable competitive advantage (SCA) of sharing economy business and market power showed that a sustainable competitive advantage had a significant influence on market power $(\beta=0.638, C R=$ 14.031, $\mathrm{p}=0.000$ ). 
Table 5. Results of the research hypothesis test.

\begin{tabular}{|c|c|c|c|c|c|c|c|c|}
\hline \multirow{2}{*}{$\begin{array}{c}\text { Type } \\
\text { H1-1-1 }\end{array}$} & \multicolumn{3}{|c|}{ Pathway } & \multirow{2}{*}{$\begin{array}{c}\text { Estimate } \\
0.313\end{array}$} & \multirow{2}{*}{$\begin{array}{c}\text { SE } \\
0.070\end{array}$} & \multirow{2}{*}{$\begin{array}{c}\text { CR } \\
4.453\end{array}$} & \multirow{2}{*}{$\frac{p \text {-Value }}{0.000}$} & \multirow{2}{*}{$\begin{array}{l}\text { Result } \\
\text { Accept }\end{array}$} \\
\hline & Consumer orientation & $\rightarrow$ & Product innovation & & & & & \\
\hline H1-1-2 & Competitive orientation & $\rightarrow$ & Product innovation & 0.070 & 0.068 & 1.036 & 0.301 & Reject \\
\hline H1-1-3 & Functional coordination & $\rightarrow$ & Product innovation & 0.188 & 0.073 & 2.582 & 0.010 & Accept \\
\hline H1-2-1 & Consumer orientation & $\rightarrow$ & Communication innovation & 0.003 & 0.068 & 0.041 & 0.967 & Reject \\
\hline H1-2-2 & Competitive orientation & $\rightarrow$ & Communication innovation & 0.266 & 0.066 & 4.035 & 0.000 & Accept \\
\hline H1-2-3 & Functional coordination & $\rightarrow$ & Communication innovation & 0.337 & 0.071 & 4.769 & 0.000 & Accept \\
\hline H1-3-1 & $\begin{array}{l}\text { Market information } \\
\text { generation }\end{array}$ & $\rightarrow$ & Product innovation & 0.429 & 0.073 & 5.883 & 0.000 & Accept \\
\hline H1-3-2 & $\begin{array}{l}\text { Market information } \\
\text { exchange }\end{array}$ & $\rightarrow$ & Product innovation & 0.092 & 0.071 & 1.296 & 0.196 & Reject \\
\hline H1-3-3 & $\begin{array}{l}\text { Response to market } \\
\text { information }\end{array}$ & $\rightarrow$ & Product innovation & 0.346 & 0.071 & 4.893 & 0.000 & Accept \\
\hline H1-4-1 & $\begin{array}{l}\text { Market information } \\
\text { generation }\end{array}$ & $\rightarrow$ & Communication innovation & 0.002 & 0.078 & 0.022 & 0.982 & Reject \\
\hline H1-4-2 & $\begin{array}{l}\text { Market information } \\
\text { exchange }\end{array}$ & $\rightarrow$ & Communication innovation & 0.413 & 0.076 & 5.457 & 0.000 & Accept \\
\hline H1-4-3 & $\begin{array}{l}\text { Response to market } \\
\text { information }\end{array}$ & $\rightarrow$ & Communication innovation & 0.216 & 0.075 & 2.862 & 0.005 & Accept \\
\hline $\mathrm{H} 2-1$ & Product innovation & $\rightarrow$ & $\begin{array}{l}\text { Sustainable competitive } \\
\text { advantage }\end{array}$ & 0.490 & 0.046 & 10.579 & 0.000 & Accept \\
\hline $\mathrm{H} 2-2$ & $\begin{array}{l}\text { Communication } \\
\text { innovation }\end{array}$ & $\rightarrow$ & $\begin{array}{l}\text { Sustainable competitive } \\
\text { advantage }\end{array}$ & 0.382 & 0.046 & 8.240 & 0.000 & Accept \\
\hline $\mathrm{H} 3$ & $\begin{array}{l}\text { Sustainable competitive } \\
\text { advantage }\end{array}$ & $\rightarrow$ & Performance & 0.638 & 0.045 & 14.031 & 0.000 & Accept \\
\hline
\end{tabular}

$\mathrm{SE}=$ Standard error; $\mathrm{CR}=$ Critical ratio .

The results of the present study were as follows. First, the significant relationship between consumer orientation and product innovation of H1-1-1 is supported by the finding of Narver et al. [15], who reported that in terms of the relationship between cultural market orientation and product innovation, the customer orientation that is based on desires that consumers were unable to express is highly likely to link to innovation if the firm has deep insight into customers. The significant relationship between functional coordination and product innovation of H1-1-3 is supported by Morgan et al. [71], who reported that the marketing capability of an organization can be strengthened by increasing the organization's responsiveness to market changes. Second, in terms of the relationship between cultural market orientation and communication innovation, activities to cope with competitor's movement will increase the firm's flexibility [72] and flexibility in marketing strategies compared to competing organizations, which will improve capabilities to develop products and service brands according to market information, and to maintain good relationships with customers and communicate with them [44]. Weerawardena and O'Cass [13] stated that it will result in accelerating innovation in the innovation process. It supports the significant relationship between competitive orientation and communication innovation of H1-2-2. The significant relationship between functional coordination and communication innovation of H1-2-3 is supported by Martin and Grbac [73], who reported that communication with customers should be considered important to continuously maintain good relationships with customers to create effective organizational capabilities. Third, the significant relationship between market information generation and product innovation of H1-3-1 is supported by the findings of Slater and Mohr [74], who stated that market creation orientation based on potential desires will increase meaningful innovations for future customers in terms of the relationship between behavioral market orientation and product innovation, and the findings of Kirca et al. [59], who reported that market orientation not only improves consumers' quality perception, loyalty, and customer satisfaction, but also positively influences innovation and new product success. The significant relationship between response to market information and product innovation of H1-3-2 is supported by the report of Yang [75], who stated that a high market response of the firm will positively influence marketing innovation because the firm can satisfy future desires that customers are unable to express. Fourth, the significant relationship between market information exchange and communication innovation of H1-4-2 is supported by Kirca et al. [59], who reported that in terms of the relationship between cultural market orientation and communication innovation, 
an organization with high market orientation will build marketing capabilities that can effectively create and exchange market information. The significant relationship between the response to market information and communication innovation of H1-4-3 is supported by previous studies reporting the organization's decision making to respond to market changes based on special information is important because it has to respond sensitively to customers' demands [76], and furthermore, market response to meet customer desires and to detect and cope with competitor's behavior will accelerate innovation for the development of new marketing mix [75]. In other words, the more the market response is strengthened, the more the firm will try to meet customers' expressed desires; such desires basically require a different response from the existing marketing mix. Fifth, the significant relationship between product innovation and a sustainable competitive advantage of H2-1 is supported by previous studies reporting that in terms of the relationship between product and communication innovation and a sustainable competitive advantage, product and service innovation is considered as a strategic competitive advantage [77], and differentiation of services (products) becomes an important source that can ultimately occupy a competitive advantage in the market [78]. Marketing innovation in the relationship between industrial customers improves the competitiveness of a firm by improving negotiation capabilities through communication and lowering interdependence [42]. Such findings support the significant relationship between communication innovation and sustainable competitive advantage of $\mathrm{H} 2-2$ in the present study. Sixth, the significant relationship between a sustainable competitive advantage and the performance of $\mathrm{H} 3$ in the present study is supported by previous studies $[8,30]$ reporting that in terms of the relationship between sustainable competitive advantage and performance, the firm's performance becomes better over time when competitive advantage is continuously maintained in the market.

\section{Conclusions}

Market orientation is the tendency of organizational activities to respond to the market demand better than competitors and to predict market changes well to create a sustainable competitive advantage and high profits. The present study identified the market orientation of sharing economy business from cultural and behavioral perspectives, and investigated it in terms of the structural relationship between marketing innovation, sustainable competitive advantage, and performance (market power). Such sharing economy business with high market orientation is expected to utilize opportunities derived from the market and improve service development to meet the desires of the target market.

The marketing implications of the present study are as follows. First, to increase product innovation, sharing economy service needs to reflect customers' responses in service development, link customer information with service development, increase customer orientation that says the understanding of customer demands is important as a competitive factor, rapid coordination of differences between service and user, share values and experience information between service and user, and a functional coordination method between service and user. Sharing economy service has to make continuous efforts to identify user's potential desires, reflect desires that users are unable to express in service development, make efforts to find opportunities in the attribute that users have difficulty expressing, and generate market information through concerns about new trends in the service that users may prefer. Furthermore, sharing economy services should measure user satisfaction systematically and regularly, either rapidly reestablish or adjust strategies when the market changes, and actively respond to market information by rapidly performing strategic alternatives according to environmental changes. Second, to increase communication innovation, sharing economy service needs to understand and share competitors' strategies, attach great importance to competitors' strengths and weaknesses and reflect them in service, increase competitive orientation by reflecting competitors' strategic behavior in service, rapidly coordinate differences between the service and user, share values and experience information, and functional coordination between the service and user. Sharing economy services should freely share information on success/failure cases about shared value service, 
monitor the level of information that satisfies users' desire, activate market information exchange by improving products/services suitable for the market, measure user satisfaction systematically and regularly, either rapidly reestablish or adjust strategies when the market changes, and actively respond to market information that requires prompt execution of strategic alternatives according to environmental changes. Third, to increase a sustainable competitive advantage, a sharing economy service should actively present innovative new product ideas, respond quickly to market demands and actively develop new products (services), and improve product innovation that actively embraces user-centered pricing policies. Sharing economy services should also have an active promotion that can express value, integrate various distribution channels for users to easily access them, and increase communication innovation that has horizontal communication with consumers. Fourth, for sharing economy services to increase market power that has a higher market share, superior quality, and brand image than competitors, sharing economy services should continuously have resources that can be a competitive advantage in the market, develop competitive advantage elements which competitors cannot imitate, and pursue sustainable competitive advantage strategies that must be continuously maintained.

Through these implications, it has been suggested that the detailed application of the market orientation of sharing economy business of the present study at the working-level can be the driving force that can create new shared value, a sustainable competitive advantage, and performance in combination with marketing innovation characteristics. Various factors and relationships that were not considered in the present study, however, need to be identified by steps systematically in the future. Research is necessary to expand variables related to marketing innovation of sharing economy business to the aspects of cost, sales, and distribution. Since the present study was focused on the scope of the utilization of integrated sharing economy products and services, the generalization of specific types of sharing economy businesses is difficult. Accordingly, research that includes characteristic factors of a specific type of sharing economy business is necessary to identify the performance of more valid sharing economy business and the differentiation of its influence.

Author Contributions: Y.K.N. and S.K. both wrote the paper and designed the survey. Y.K.N. contributed to the writing of the paper and conducted the survey and data analysis. S.K. suggested research ideas and contributed to the writing and revision of the paper. H.Y.J. assisted in conducting the survey and data analysis.

Funding: This work was supported by the Ministry of Education of the Republic of Korea and the National Research Foundation of Korea (NRF-2016S1A5A2A03926167).

Conflicts of Interest: The authors declare no conflict of interest.

\section{References}

1. Lifkin, J. The Zero Marginal Cost Society; Palgrave McMillan: New York, NY, USA, 2014.

2. Cohen, B.; Kietzmann, J. Ride on! Mobility business models for the sharing economy. Organ. Environ. 2014, 27, 279-296. [CrossRef]

3. Belk, R. You are what you can access: Sharing and collaborative consumption online. J. Bus. Res. 2014, 67, 1595-1600. [CrossRef]

4. Stephany, A. The Business of Sharing: Making it in the New Sharing Economy; Palgrave Macmillan: New York, NY, USA, 2015.

5. Möhlmann, M. Collaborative consumption: Determinants of satisfaction and the likelihood of using a sharing economy option again: Collaborative consumption-30 determinants of satisfaction and the likelihood of using a sharing economy option again. J. Consum. Behav. 2015, 14, 193-207. [CrossRef]

6. Nadkrni, S.; Hermann, P. CEO personality, strategic flexibility, and firm performance: The case of the Indian business process outsourcing industry. Acad. Manag. J. 2010, 53, 1050-1073. [CrossRef]

7. Cadogan, J.W.; Sundqvist, S.; Puumalainen, K.; Salminen, R.T. Strategic flexibilities and export market-oriented behavior and the export environment. Eur. J. Mark. 2012, 46, 1418-1452. [CrossRef]

8. Kumar, V.; Jones, E.; Venkatesan, R.; Leone, R.P. Is market orientation a source of sustainable competitive advantage or simply the cost of competing. J. Mark. 2011, 75, 16-30. [CrossRef] 
9. Vorhies, D.W.; Harker, H.M. The capabilities and performance advantages of market-driven firms: An empirical investigation. Aust. J. Manag. 2000, 25, 145-172. [CrossRef]

10. Langerak, F. Effects of market orientation on the behaviors of salespersons and purchasers, channel relationships and performance of manufactures. Int. J. Res. Mark. 2001, 18, 221-234. [CrossRef]

11. Jang, H.Y. Relationships among market orientation, marketing performance and CRM performance: Focused on the modulating effects of customer asset value. Acad. Cust. Satisf. Manag. 2013, 15, 1-27.

12. Christensen, C.M.; Bower, J.L. Customer power, strategic investment, and the failure of leading firms. Strateg. Manag. J. 1996, 17, 197-218. [CrossRef]

13. Weerawardena, J.; O'Cass, A. Exploring the characteristics of the market-driven firms and antecedents to sustained competitive advantage. Ind. Mark. Manag. 2004, 33, 419-428. [CrossRef]

14. Shergill, G.S.; Nargundkar, R. Market orientation, marketing innovation as performance drivers: Extending the paradigm. J. Glob. Mark. 2005, 19, 27-44. [CrossRef]

15. Narver, J.C.; Slater, S.F.; MacLachlan, D.L. Responsive and proactive market orientation and new product success. J. Prod. Innov. Manag. 2004, 21, 334-347. [CrossRef]

16. Yang, Y.I.; Chung, J.H. The impact of market orientation on marketing capability and performance in the hotel industry. J. Hosp. Tour. Stud. 2006, 8, 44-56.

17. Jeong, G.Y. The effect of entrepreneurial orientation on marketing capability. Korean Corp. Manag. Rev. 2017, 24, 75-106.

18. Kohli, A.K.; Jaworski, B.J. Market orientation: The construct, research propositions, and managerial implications. J. Mark. 1990, 54, 1-18. [CrossRef]

19. Jaworski, B.J.; Kohli, A.K. Market orientation: Antecedents and consequences. J. Mark. 1993, 57, 52-70. [CrossRef]

20. Hills, S.B.; Sarin, S. From market driven to market driving: An alternate paradigm for marketing in high technology industries. J. Mark. Theor. Pract. 2003, 11, 13-24. [CrossRef]

21. Yang, Y.I. The relationships of market orientation, marketing/R\&D interface, strategic flexibility and performance, and the moderating effect of environmental turbulence in the domestic manufacturing firms: From the perspective of CEO. J. Prof. Manag. 2013, 16, 141-167.

22. Kim, W.C.; Mauborgne, R. Value innovation: The strategic logic of high growth. Harv. Bus. Rev. 1997, 75, 103-112.

23. Levitt, T. Marketing success through differentiation of anything. Harv. Bus. Rev. 1980, 58, 83-91.

24. Schlegelmilch, B.B.; Ram, R. The impact of organizational and environmental variables on strategic market orientation: An empirical investigation. J. Glob. Mark. 2000, 13, 111-127. [CrossRef]

25. Conduit, J.; Mavondo, F.T. How critical in internal customer orientation to market orientation? J. Bus. Res. 2001, 51, 11-24. [CrossRef]

26. Park, M.S.; Lee, D.J. The role of integrating mediators between market orientation and performance of hotels. Asia Mark. J. 2002, 4, 55-78.

27. Han, J.K.; Kim, N.W.; Srivastava, R.K. Market orientation and organizational performance: Is innovation a missing link? J. Mark. 1998, 62, 30-45. [CrossRef]

28. Kim, J.Y.; Lee, S.H. An examination of the differences in perceptions of generic characteristics of innovative new products between innovative and imitative consumers for product innovation types. J. Mark. Manag. Res. 2016, 21, 75-101.

29. Tellis, G.J.; Yin, E.; Bell, S. Global consumer innovativeness: Cross-country differences and demographic commonalities. J. Int. Mark. 2009, 17, 1-22. [CrossRef]

30. Naidoo, V. Firm survival through a crisis: The influence of marketing orientation, marketing innovation and business strategy. Ind. Mark. Manag. 2010, 39, 1311-1320. [CrossRef]

31. Kotabe, M.; Srinivasan, S.S.; Aulakh, P.S. Multinationality and firm performance: The moderating role of R\&D and marketing capabilities. J. Int. Bus. Stud. 2002, 33, 79-97.

32. Aaker, D. Managing Brand Equity, Capitalizing on the Value of a Brand Name; Free Press: New York, NY, USA, 1991.

33. Cobb-Welgren, C.J.; Ruble, C.A.; Dunthu, N. Bland preference and purchase intent. J. Mark. 1995, $24,25-40$.

34. Ailawadi, K.L.; Borin, N.; Farris, P.W. Market power and performance: A cross-industry analysis of manufacturers and retailers. J. Retail. 1995, 71, 211-248. [CrossRef] 
35. Day, G.S.; Wensley, R. Assessing advantage: A framework for diagnosing competitive superiority. J. Mark. 1988, 52, 1-20. [CrossRef]

36. Tamayo-Torres, I.; Ruiz-Moreno, A.; Verdu, A.J. The moderating effect of innovative capacity on the relationship between real options and strategic flexibility. Ind. Mark. Manag. 2010, 39, 1120-1127. [CrossRef]

37. Schilling, M. Strategic Management of Technological Innovation; McGraw-Hill: New York, NY, USA, 2008.

38. Yoo, J.M.; Kim, S.H.; Yi, Y.J. Determinants of perceived innovativeness and their relationship with intention of product adoption: Focusing on consumers' perspectives. Korean Mark. Rev. 2006, 21, 27-52.

39. Venkatesh, V.; Davis, F.D. A theoretical extension of the technology acceptance model: Four longitudinal field studies. Manag. Sci. 2000, 46, 186-204. [CrossRef]

40. Atuahene-Gima, K.; Ko, A. Effects of market and entrepreneurship orientation alignment on production innovation. Organ. Sci. 2001, 12, 54-74. [CrossRef]

41. Park, J.Y.; Choi, S.S.; Hong, S.K. The effects of market orientation, marketing capability on competitive advantage and performance in SME. Korean J. Bus. Adm. 2011, 24, 1115-1137.

42. Zerbini, F.; Goldetto, F.; Gilbert, M. Marketing of competence: Exploring the resource-based content of value for customers through a case study analysis. Ind. Mark. Manag. 2007, 36, 784-798. [CrossRef]

43. Sargeant, A. Relationship fundraising: How to keep donors loyal? Nonprofit Manag. Leadersh. 2001, 12, 177-192. [CrossRef]

44. Vorhies, D.W.; Morgan, N.A. Benchmarking marketing capabilities for sustainable competitive advantage. J. Mark. 2005, 69, 80-94. [CrossRef]

45. Sigalas, C. Competitive advantage: The know unknown concept. Manag. Dec. 2015, 53, 2004-2016. [CrossRef]

46. Han, S.M.; Ha, Y.W.; Jang, D.R. Competitive Advantage Marketing Strategy, 4th ed.; Parkyeongsa: Seoul, Korea, 2018.

47. Porter, M.E. Competitive Advantage: Creating and Sustaining Superior Performance; Free Press: New York, NY, USA, 1985.

48. Hill, W.L.; John, G.R. Strategic Management: An Integrated Approach; Houghton Mifflin Company: Boston, MA, USA, 2009.

49. Reid, R.D.; Sanders, N.R. Operations Management, 4th ed.; Wiley: Hoboken, NJ, USA, 2012.

50. Jaakkola, M.; Moller, K.; Parvinen, P.; Evanshitzky, H.; Muhlbacher, H. Strategic marketing and business performance: A study in three European engineering countries. Ind. Market. Manag. 2010, 39, 1300-1310. [CrossRef]

51. Dwyer, L.M.; Cvelbar, L.K.; Edwards, D.J.; Mihalic, T.A. Tourism firms' strategic flexibility: The case of Slovenia. Int. J. Tour. Res. 2014, 16, 377-387. [CrossRef]

52. Wei, Z.; Yi, Y.; Guo, H. Organizational learning ambidexiterity, strategic flexibility and new product development. J. Prod. Innov. Manag. 2014, 31, 832-847. [CrossRef]

53. Itami, H. Mobilizing Invisible Assets; Harvard University Press: Boston, MA, USA, 1987.

54. Barney, J. Firm resources and sustained competitive advantage. J. Manag. 1991, 17, 99-120. [CrossRef]

55. Leonard-Barton, D. Core capabilities and core rigidities: A paradox on managing new product development. Strateg. Manag. J. 1992, 13, 111-125. [CrossRef]

56. Won, J.Y.; Ryu, S.L. The effect of firm life-cycle and competitive strategy on performance persistence. Korean Acc. J. 2016, 25, 33-65.

57. Banker, R.D.; Mashruwala, R.; Tripathy, A. Does a differentiation strategy lead to more sustainable financial performance than a cost leadership strategy? Manag. Dec. 2014, 52, 872-896. [CrossRef]

58. O'Cass, A.; Ngo, L.V. Market orientation versus innovative culture: Two routes to superior brand performance. Eur. J. Mark. 2007, 40, 868-887. [CrossRef]

59. Kirca, A.H.; Jayachandranm, H.S.; Bearden, W.O. Market orientation: A meta-analytic review and assessment of its antecedents and impact on performance. J. Mark. 2005, 69, 24-41. [CrossRef]

60. Jun, Y.S.; Park, J.Y. The effect of the service employee's job satisfaction, customer orientation, and management performance by the market orientation in travel agency: Focused on listed travel agency. Korean J. Tour. Res. 2011, 26, 527-545.

61. Lee, Y.K.; Jang, K.R.; Kwon, Y.J. The impact of market orientation on service quality, customer satisfaction, switching costs and word-of-mouth communication. J. Tour. Sci. 2000, 24, 57-74.

62. Kim, J.W.; Jeon, K.H.; Lee, S.G. The effect of market orientation on performance of channel relationships: Distributors' perspective. Korean Mark. Rev. 2001, 16, 93-114. 
63. Hult, T.G.; Ketchen, D.J. Does market orientation matter? A test of the relationship between positional advantage and performance. Strateg. Manag. J. 2001, 22, 899-906. [CrossRef]

64. Im, S.; Workman, J.P. Market orientation, creativity and new product performance in high-technology firms. J. Mark. 2004, 68, 114-132. [CrossRef]

65. Vorhies, D.W.; Harker, M.; Rao, C.P. The capabilities and performance advantages of market driven firms. Eur. J. Mark. 1999, 33, 1172-1201. [CrossRef]

66. Narver, J.C.; Slater, S.F. The effect of a market orientation on business profitability. J. Mark. 1990, 54, $20-35$. [CrossRef]

67. Park, G.H. The influence of market orientation and export marketing capabilities on export performance. Int. Bus. Rev. 2009, 13, 93-121. [CrossRef]

68. Von Hippel, E. A source of novel product concepts. Manag. Sci. 1986, 32, 791-805. [CrossRef]

69. Gulati, R.; Nohria, N.; Zaheer, A. Strategic networks. Strateg. Manag. J. 2000, 21, 203-215. [CrossRef]

70. Day, G.S. The capabilities of marketing driven organizations. J. Mark. 1994, 58, 37-52. [CrossRef]

71. Morgan, N.A.; Vorhies, D.W.; Mason, C.H. Research notes and commentaries: Market orientation marketing capabilities and firm performance. Strateg. Manag. J. 2009, 30, 909-920. [CrossRef]

72. Johnson, J.L.; Lee, R.P.; Saini, A.; Grohmann, B. Market-focused strategic flexibility: Conceptual advances and an integrative model. J. Acad. Mark. Sci. 2003, 31, 74-89. [CrossRef]

73. Martin, J.H.; Grbac, B. Using supply chain management to leverage a firm's market orientation. Ind. Mark. Manag. 2003, 32, 25-38. [CrossRef]

74. Slater, F.S.; Mohr, J.J. Successful development and commercialization of technological innovation: Insights based on strategy type. J. Prod. Innov. Manag. 2006, 23, 26-33. [CrossRef]

75. Yang, Y.I. The study on the relationships among market orientation, marketing innovation, sustained competitive advantage and performance: From the perspective of CEO. J. Prof. Manag. 2012, 15, 115-138.

76. Gonzalez, B.O.; Gonxalez, B.J.; Munoz, G.P.A. Role of entrepreneurship and market orientation in firms' success. Eur. J. Mark. 2002, 43, 500-522. [CrossRef]

77. Enz, C.A.; Siguaw, J.A. Revisiting the best of the vest: Innovations in hotel practice. Cornell Hotel Q. 2003, 44, 115-123. [CrossRef]

78. Kim, T.G.; Lee, G.H. Examining social capital and knowledge sharing as antecedents of service innovativeness and business performance in the hotel industry: An application of the resource-based view (RBV) theory. J. Tour. Sci. 2010, 34, 13-36. 